with the aid of the new computer. Here also is the College's photocopier, addressograph (now almost obsolete), a duplicator and a new envelope labelling machine.

As we return to the front hall we pass the stairs leading to the basement, and until last month those who cared to descend would find there something like five rooms, of which one was in use as a kitchen, and sundry pantries and cupboards. Redeveloping the whole of this large area has now started, to provide some lecture accommodation, catering facilities, somewhere for members to meet, and a small staff room. This work should be completed by the end of 1980 .

One of the College's first priorities on moving to Belgrave Square was to rebuild a flat for a married couple to act as Caretaker and Housekeeper, and these posts have been very ably filled by Mr and Mrs Brooks.

The small Mews House is at present occupied by a tenant, but in a few years time it will revert to the College. Before then careful consideration will need to be given to its future, with the help, of course, of professional advice.

Alexander Walk

\title{
The Work of a College Section
}

\section{Social and Community Psychiatry}

At the Annual Meeting of the College in July 1979 the Social and Community Psychiatry Group was constituted a Specialist Section.

The Group was founded in 1973. An open meeting had been held on 18 June of that year which was attended by 25 members of the College, with letters from 120 others indicating support. The first formal meeting was held in October when the Executive Committee was elected, which first met on 30 November 1973. Working Groups on 'Epidemiology', 'Organization of Services and Review of DHSS Policies' and 'Health Promotion and the Prevention of Psychiatric Illness' were set up.

The Executive Committee has met regularly to receive reports from the Working Parties and has organized a number of open meetings, as on rehabilitation at the 1978 Annual Meeting and the evaluation of services in February 1979.

In March 1977 the Executive Committee reviewed the activities of the Working Parties. The Epidemiology Working Party concluded that they had no further specific projects in hand. The Working Party on Services had been particularly concerned with commenting on papers from the DHSS, and it was agreed that this function would be needed in future. The Working Party on Preventive Psychiatry felt it would be appropriate to stop meeting as a group at this stage.

The activities of the three Working Parties have been summarized by their Chairmen as follows:

\section{Epidemiology Working Party}

Members of this Working Party addressed themselves to the issue of confidentiality of medical records. It was noted that there was a growing problem of doctors' refusal to fill in patients' names on Mental Health Enquiry forms and that this threatened the continuance of record linkage systems. A document was prepared dealing with confidentiality of medical records and this was undertaken by Professor Wing, Dr Leff and Dr Baldwin. The document was published in the British Journal of Psychiatry, (May 1976, 128, 417-27), and was discussed by Dr Leff at the Quarterly Meeting in the same month.

\section{Working Party on Services}

This Working Party defined its role as discussing "those aspects of services which were not specifically in the province of other Specialist Sections, although matters of common interest might be seen from different points of view'. A number of specific topics were considered, including:

(a) The role of the psychiatrist in the Mental Health Care Planning Team. A report on this subject was published in News and Noles (December 1975).

(b) The need for secure provision in the District General Hospital Psychiatric Unit. A working paper on the subject was prepared in conjunction with the Forensic Psychiatry Section.

(c) In February 1977 a two-day symposium was held on the topic of 'Models of Community Psychiatry'.

(d) The Working Party was responsible for the organization of sessions at College Meetings, including a session on 'Planning for Mental Health Services' at the Annual Meeting in July 1975 and jointly with the Group for the Psychiatry of Old Age at the November Quarterly Meeting in 1976.

Projects undertaken by members of the Group included preparation of a discussion document on the Relationship between the Community Psychiatrist and the General Practitioner and investigations into the Relationship between Health and Social Services and the Hospital Advisory Service Reports relating to Community Services. Comments were prepared on various official reports.

Finally, the Working Party was responsible for providing 
reports for the College Committee preparing evidence for the Royal Commission on the National Health Service.

Working Party on Preventive Psychiatry

The Preventive Psychiatry Workshop prepared its first outline of the field in the form of a report to the parent committee entitled 'What is Preventive Psychiatry?' in January 1975 .

The Workshop was enlarged by co-option of a general practitioner, a community physician, two social workers, a clergyman, a health visitor, an educational psychologist, a community psychiatric nurse and a member of the staff of The Volunteer Centre. This group produced a report 'The Use of Psychiatric Resources for Indirect Service to Patients' which was published in the Bulletin (February 1978).

A paper entitled 'Models of Community Psychiatry: Prevention' was read by Dr C. Parkes at the CIBA Foundation Symposium in February 1978.

A paper 'The Use of Community Care in Prevention' was read by Dr C. Parkes at the Anniversary Conference of the Mental Health Foundation at Oxford on 24 September 1977.

A Conference, 'The Volunteer as a New Resource in the Community Psychiatric Team', was organized by the Workshop and held jointly with The Volunteer Centre in March 1978. A report is being prepared and will be circulated to Hospital Volunteer Organizers throughout Britain.

\section{Membership of the Group}

In Spring 1978 the College records showed that there were 383 Members and Fellows who were known to have expressed an interest in the Group (328 resident in UK and 55 overseas). Replies to a memorandum distributed in 1978 raised the membership of the Group to 483 , distributed as follows-United Kingdom 362, Irish Republic 18, Other Overseas 103.

\section{Recent Meetings}

A Scientific Meeting was held in November 1979 at the Institute of Psychiatry with one session devoted to papers on Therapeutic Communities and another to Psychiatry and General Practice. The first Business Meeting was held then and the Executive Committee elected.

A one-day symposium on Community Psychiatric Nursing, jointly sponsored by the Community Psychiatric Nursing Association and the Royal College of Nursing, was held in February of this year.

\section{Present Activities}

Three new Working Parties were established in 1978.

\section{(a) Working Party on Rehabilitation}

This working party was set up at the request of the Department of Health. The chairman is Professor J. K. Wing and the joint secretaries are Dr Brenda Morris and Mrs Peggy Pyke-Lees. Some 30 people from psychiatry and allied professions are taking part. Two sub-groups are collating replies and preparing reports.

\section{(b) Working Party on Norms}

This Working Party was set up, under the chairmanship of Professor S. Hirsch, to consider DHSS guidelines on the scale and position suggested for psychiatric units in general hospitals. It had been noted that planning committees at Regional and Area level were already departing from these guidelines which have not been modified for several years. The party decided to approach the work in two ways. First to circulate a questionnaire to a sample of about 30 hospitals thought to provide a good standard of care, but representing different ecological conditions. Second, to try to get one-day prevalence data from psychiatric case registers from around the country, and this plan is to be considered at a forthcoming meeting of representatives from the psychiatric case registers organized by Professor Wing. The aim of these surveys is to determine the numbers of places actually used for acute psychiatric services and the extent of variation in different circumstances. With such an initial assessment in hand a more detailed approach to the problem will be considered.

\section{(c) Working Party on Community Psychiatric Nursing}

This Working Party was asked to consider the role of the community psychiatric nurse, lines of responsibility and communication, relationship with other professional groups and the number of community psychiatric nurses required in the future.

Dr A. C. Brown is chairman and convener. Evidence has been gathered and draft comments and proposals are being prepared for discussion by the College.

\author{
J. P. LEFF, Chairman \\ A. C. BRown, Secretary \\ Social and Community Psychiatry Section
}

